\title{
Assessment of Gastric Acidity by Conventional Endoscopy With Serological Gastric Markers
}

\author{
Byung Chul Kimª, d, Mi Ae Songa, Sung Ho Kwon ${ }^{\mathrm{b}}$, Min Ji Kim ${ }^{\mathrm{c}}$
}

\begin{abstract}
Background: Gastric acidity could determine Helicobacter pylori $(H$. pylori)-associated gastritis patterns. In reverse, H. pylori infection could lead disturbance in gastric acid secretion. We attempted to elucidate gastric acid status by conventional endoscopy with pepsinogen test.

Methods: A total of 196 subjects who visited our health promotion center were consecutively enrolled and evaluated by conventional endoscopy, and blood examinations with pepsinogen I, II, and fasting serum gastrin were conducted. As a Japanese study suggested that in $H$. pylori-positive subjects the cutoff value was PG I/II ratio $\leq 2.7$ for hypochlorhydia, PG $\mathrm{I} / \mathrm{II}$ ratio $\geq 3.3$ for hyperchlorhydria. Based on these serological data, we compared conventional endoscopic images with each acid level.
\end{abstract}

Results: It showed that for hypoacidity, older age, and most of the $H$. pylori-associated endoscopic appearances featuring mucosal inflammation and more atrophy of corpus or antrum were in favor of hypoacidity in closed type. Mucosal appearances showing severe corpus atrophy and remnant gastritis with advanced background atrophy determine hypoacidity in open type. For hyperacidity, mucosal appearances featuring intact mucosa and less severe atrophy were associated with hyperacid status. Male gender, antrum camouflage were also involved in hyperacidity.

Conclusions: Conventional endoscopy with pepsinogen test could be useful in gastric acid assessment.

Keywords: Gastric acid secretion; Serum pepsinogen; Helicobacter pylori

\section{Introduction}

The level of gastric acidity is associated with various upper

Manuscript submitted February 27, 2018, accepted March 26, 2018

${ }^{a}$ Department of Internal Medicine, Hangsarang Hospital, Ulsan, Korea bepartment of Internal Medicine, Kangnam medical clinic, Ulsan, Korea ${ }^{c}$ College of Agriculture and Life Sciences, Kyungpook National University, Daegu, Korea

${ }^{\mathrm{d} C o r r e s p o n d i n g ~ A u t h o r: ~ B y u n g ~ C h u l ~ K i m, ~ D e p a r t m e n t ~ o f ~ I n t e r n a l ~ M e d i c i n e, ~}$ Hangsarang Hospital, Nam-gu, Ulsan 680-806, Korea.

Email: orion828@naver.com

doi: https://doi.org/10.14740/gr980w gastrointestinal tract diseases, and high or normal acid status is correlated with duodenal ulcerations or gastroesophageal reflux diseases $[1,2]$. On the contrary, low or profoundly low acid secretion is frequent in gastric ulcerations or gastric cancers $[3,4]$. A major component that could influence gastric acid secretion is Helicobacter pylori (H. pylori) infection in stomach. Furthermore, local acid production is a determining factor for prevalence of corpus-predominant gastritis with $H$. pylori infection [5], and acidity of affected subject can determine topographic patterns of $H$. pylori-associated gastritis, which result in different upper gastrointestinal diseases. Antral-predominant gastritis is a predominant pattern in duodenal ulcer patients with high acid secretion, and severity of corpus gastritis caused by $H$. pylori proportionally decreases gastric acid output leading to corpus-predominant atrophic gastritis in patients with low acid production [6]. Based on these findings, assessing acid level in subjects with $H$. pylori-associated gastritis is important to anticipate future upper gastrointestinal diseases like peptic ulcer or gastroesophageal reflux or even gastric cancer (GC). Uemura et al revealed importance of corpus dominant gastritis as a GC risk factor [7], and Correa suggested that $H$. pylori caused chronic gastritis, and especially corpus gastritis that was associated with loss of parietal cell mass resulting in hypochlorhydria or achlorhydria which was involved in production of carcinogenic compounds [8]. Consequently if we could sort out subjects with disturbed acid secretion based on conventional endoscopic findings, it might be a helpful guidance to identify the subjects with future gastrointestinal diseases including gastric cancer, especially for physicians in Korea, who perform biennial endoscopic gastric cancer screening. Ijima et al revealed the correlation between specific cutoff serum pepsinogen (PG) values and gastric acidity based on endoscopic gastrin test [9]. The authors showed that in H. pylori-positive subjects the cutoff value was PG I/ II ratio $\leq 2.7$ for hypochlorhydria, PG I/II ratio $\leq 2.2$ for profound hypochlorhydria, and PG I/II ratio $\geq 3.3$ for hyperchlorhydria; and they proved usefulness of PG test in assessing gastric acidity. Nomura et al $[10,11]$ revealed various conventional endoscopic appearances of $H$. pylori-infected gastric mucosa, which were correlated well with histological features like a mucosal inflammation or atrophy. Cho et al [12] showed three representative forms of $H$. pylori infected gastric mucosa (body type A, B and C). Kimura and Takemoto demonstrated that increased level of endoscopic atrophic border (EAB) was associated with decreased tendency of acid secretion [13]. $\mathrm{EAB}$ and various endoscopic appearances featuring mucosal inflammation or atrophy could be useful in anticipating gastric 


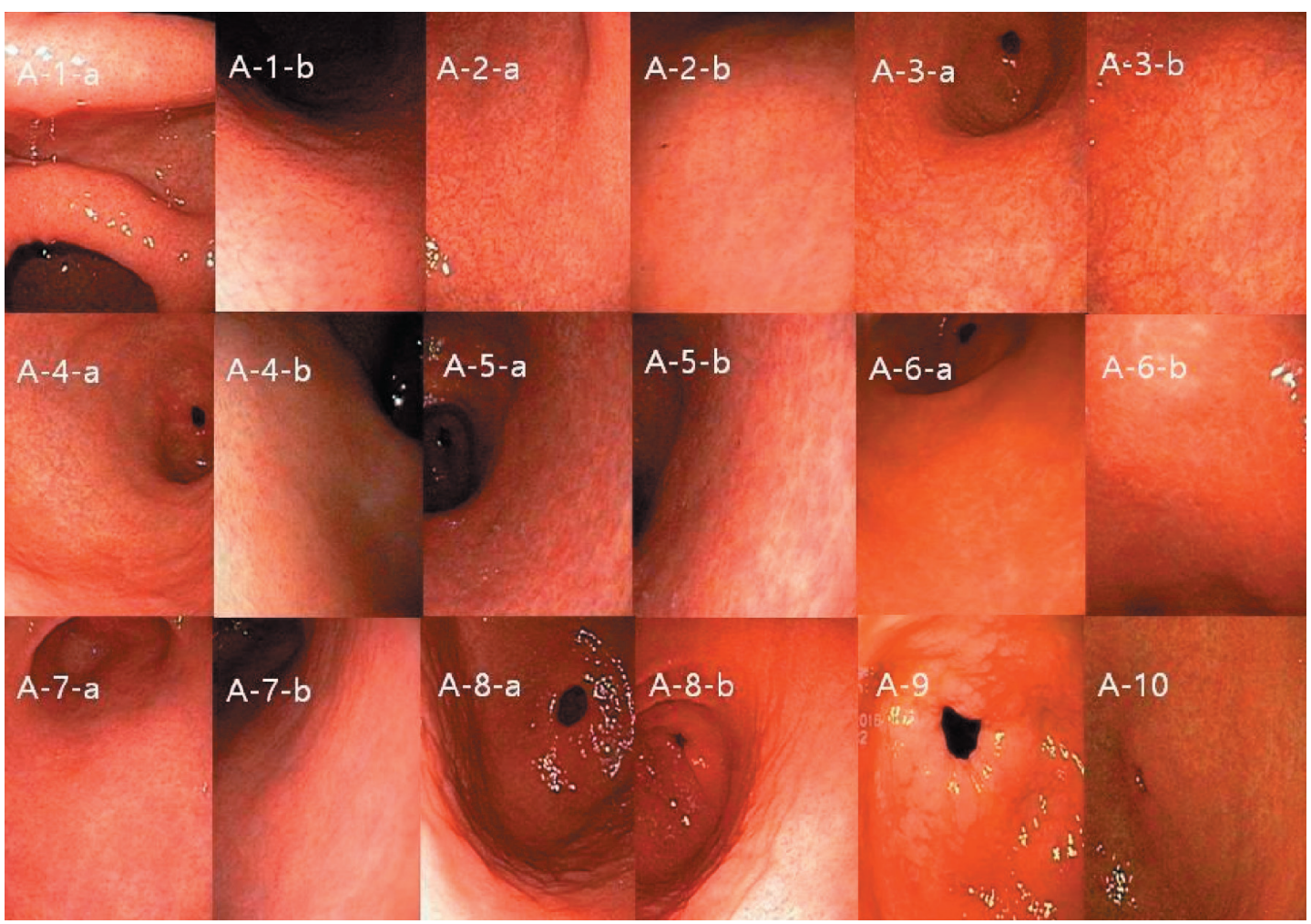

Figure 1. Representative mucosal findings of antrum. (A-1) Normal antrum-in angle and proximal antrum lesser curvature side, RAC could be seen (A-1-a), RAC in proximal antrum greater curvature side also could be seen in right sided image (A-1-b). (A-2) Normal antrum vessel structure might be seen in remote (A-2-a), but RAC could be found between vessels in close up image (right sided image (A-2-b)). (A-3) Antrum visible vessel (A_VV) (A-3-a)-there are not any RAC between vessels (right sided close up image (A-3-b)). (A-4) Antrum visible vessel break (A_VV_B)-visible mucosal differences in thickness and color between antrum and low body greater curvature side (A-4-a) and no RAC on right sided close up view (A-4-b). (A-5), (A-6) Two representative figures of antrum camouflage (A_CAM)-mosaic like mucosal change with peripheral white grooves (A-5-a, A-6-a), both right sided close up views clearly show peripheral white grooves, and some erythematous mucosal change could enhance detection of CAM (A-5-b, A-6-b). (A-7) Excluded form of similar A_CAM-mosaic like mucosal image similar to A-5 or A-6 (A-7-a), however in close up view no peripheral white grooves (A-7-b). (A-8) Antrum mucosal edema (A_ME)-soft swelling of mucosa with mosaic pattern accompanying dark peripheral grooves (A-8-a, A-8-b). (A-9) Antrum intestinal metaplasia-whitish plaques were scattered on the mucosal surface. (A-10) Antrum diffuse erythema (A_DE)-any dark or light red colors scattered diffusely on the mucosa.

acidity. Based on these endoscopic and serological findings, we attempted to find conventional endoscopic images corresponding to each acid level.

\section{Materials and Methods}

\section{Subjects and endoscopic examinations}

A total of 196 subjects, who visited our health promotion center from January 2016 to September 2016 for screening endoscopy and had H. pylori-associated gastric mucosal appearances mainly based on findings of Nomura et al and Cho et al [10-12] were consecutively enrolled for the present study. All of them showed positive H. pylori test (rapid urea test using CLO Helicobacter-detection kits (Asan Pharm Co., Ltd., Seoul, Korea), sample for CLO test were taken from low body greater curvature side of stomach). Each representative mucosal finding is shown in Figures 1 and 2. Subjects were excluded from the study if they had history of $H$. pylori eradication or if they had been taking any medicine influencing gastric mucosal appearance (any acid suppressive medicines or non-steroidal anti-inflammatory agent) within 8 weeks prior to examination; also we excluded subjects with any past or ongoing medical illness like liver or heart problem or malignant diseases. Because we explore gastric mucosal abnormalities only by visual images, subjects having no discernible EAB with normal looking gastric mucosa and $H$. pylori test positive were excluded. All the subjects had already been requested for H. pylori test and PG study for GC screening in a prequestionnaire. They were examined with conventional white light endoscopy using a GIF-Q150 (Olympus Co., Tokyo, Japan) and endoscopic mucosal images were collected for each individual with each type of EAB suggested by Kimura and Takemoto [13] (Table 1). All the endoscopic procedures were performed by the main author to avoid inter-observer variability. This study was approved by Korea National Institute 


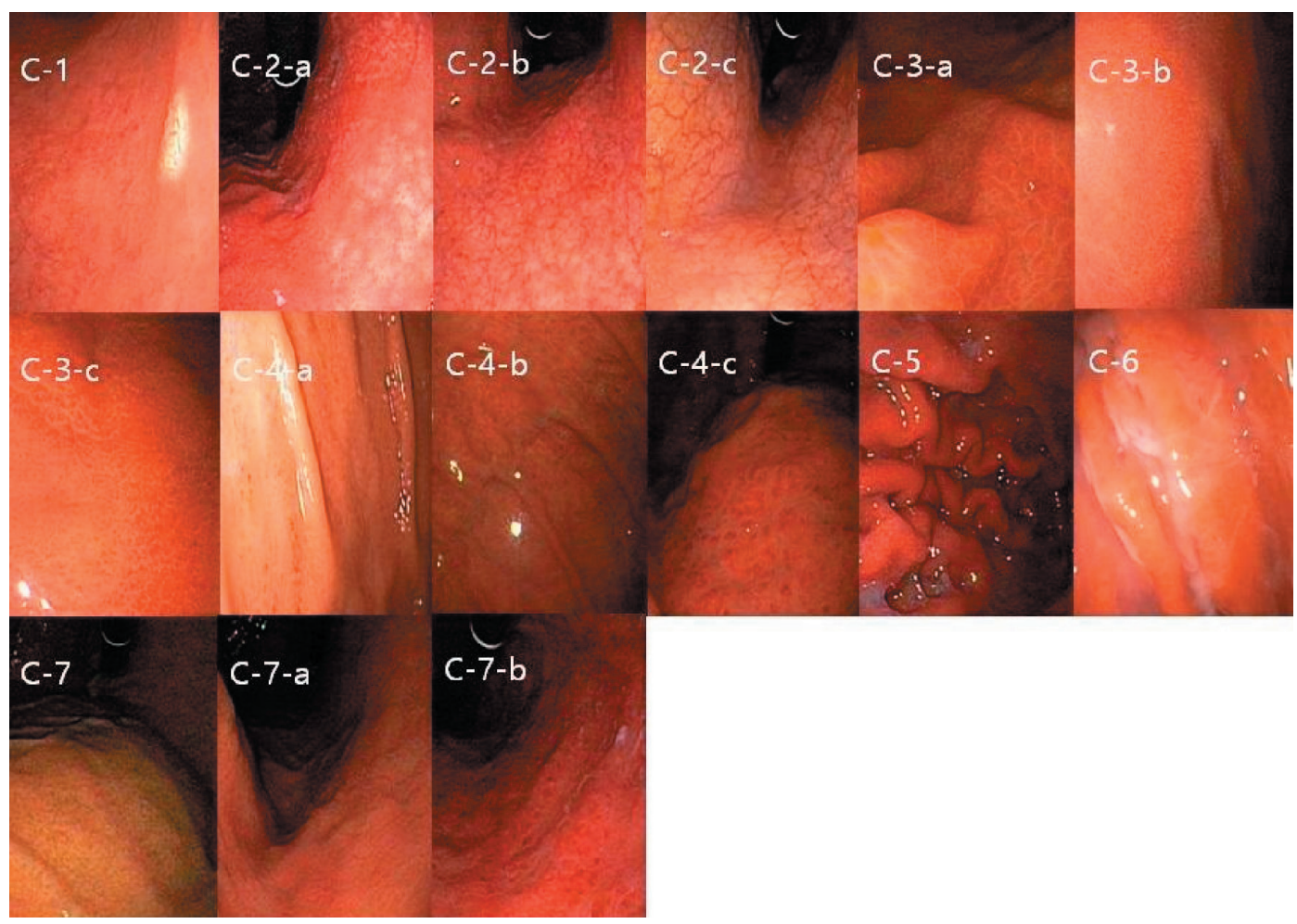

Figure 2. Representative mucosal findings of corpus. (C-1) Body xanthoma(B_XAN)-yellow white spot on the gastric mucosa. (C-2) Body visible vessel (B_VV)-graded as 3 when prominent and clear vessel marking in body lesser curvature side (C-2-c), and 2 when visible vessel mingled with irregular mucosa (C-2-b), 1 when only visible mucosal change in body LC side (C-2-a). (C-3) Body type A, B, and C (B_typeA, B_type B and B_type C)-A: mosaic-like appearance (C-3-a); B: diffuse homogenous redness (C-3-b); C: untypical (C-3-C). (C-4) Body spotty erythema (B_SE)-multilple red spots on the mucosa, graded as 1 when it could be seen only in body greater curvature (C-4-a) and 3 when clearly seen in fundus and body (C-4-C), and 2 when observed but neither 1 nor 3 (C-4-b). (C-5) Body rugal hyperplastic gastritis (B_RHG)-when gastric fold width was equal or over $5 \mathrm{~mm}$ with the aid of opening width $(7 \mathrm{~mm})$ of biopsy forcep despite sufficient aeration. (C-6) Body exudate (B_EXU)-white mucinous fluid sticking to the mucosa. (C-7) Body regular arrangement of collecting venule (B_RAC). (C-7-a), (C-7-b) Body diffuse erythema (B_DE)-erythematous mucosal change graded as 1 when it could be identified by close-up observation of mucosa due to light red color (C-7-a) and 2 when easily identified at some distance due to dark red color (C-7-b).

for Bioethics Policy (KoNIBP)

\section{Serum pepsinogen and gastrin levels}

Fasting blood samplings for serum PG test and gastrin were done before each endoscopy session, and the samples were centrifuged immediately at $4{ }^{\circ} \mathrm{C}$. Serum concentrations of PG $\mathrm{I}$ and II were measured by a latex-enhanced turbidimetric immunoassay (HBI Co., Anyang, Korea), and PG I to PG II (PG I/II) ratio was calculated. Each centrifuged serum for gastrin was stored frozen at $-20^{\circ} \mathrm{C}$ until further assay and measured by GASTRIN ( ${ }^{125} \mathrm{I}$ ) Radioimmunoassay Kit (MP Biomedicals Korea, MP bio). Gastric acid status was classified as PG I/II ratio $\leq 2.7$ for hypoacid, PG I/II ratio $>2.7$ or $<3.3$ for normoacid, PG I/II ratio $\geq 3.3$ for hyperacid [9].

\section{Data analysis}

All the endoscopic characteristics were graded as scores like
EAB as 1 to 6 , body visible vessel as 0 to 3 , body spotty erythema as 0 to 3 , body diffuse erythema as 0 to 2 , and others were as 0 to 1 . We categorized the subjects into groups based on acid status (hypoacid, normoacid and hyperacid). The statistical differences between each endoscopic parameter between the groups were assessed by one-way ANOVA with Tukey multiple comparison test. All P-value $<0.05$ were considered as statistically significant. We used SPSS version 18.0 for Windows Software (SPSS Inc., Chicago, IL, USA), and performed binary logistic regression analysis with an enter method in univariate and with a forward method in multivariate analyses to obtain odds ratios (OR) of each endoscopic findings for hypoacid or hyperacid group. The data were further analyzed based on EAB like closed and open type. We designated body visible vessel, body spotty erythema, body diffuse erythema and $\mathrm{EAB}$ as continuous variables and the other parameters as categorical variables. As a forward method in binary logistic regression only reports meaningful results in the last step of variables in the equation table, we showed the same report in the multivariate analyses. We consider OR $(>1)$ as risk factor and OR $(<1)$ as protective feature. Protec- 
Table 1. Endoscopic Parameters

\begin{tabular}{|c|c|c|c|}
\hline $\begin{array}{l}\text { Endoscopic } \\
\text { feature }\end{array}$ & Biology of feature & Scales & Note \\
\hline $\begin{array}{l}\text { Body xanthoma } \\
\text { (B_XAN) }\end{array}$ & $\begin{array}{l}\text { Suggestive of } H \text {. pylori- } \\
\text { associated gastritis } \\
\text { with surrounding more } \\
\text { atrophic mucosa }\end{array}$ & Grade 0: do not exist; Grade 1: exist & $\begin{array}{l}\text { Yellow white spot on } \\
\text { the gastric mucosa }\end{array}$ \\
\hline $\begin{array}{l}\text { Body visible } \\
\text { vessel (B_VV) }\end{array}$ & Atrophy of body mucosa & $\begin{array}{l}\text { Grade } 0 \text { : do not exist; Grade 1: only visible } \\
\text { mucosal change in body lesser curvature; } \\
\text { Grade } 2 \text { : visible vessels mingled with irregular } \\
\text { mucosa; Grade } 3 \text { : when prominent, and clear } \\
\text { vessels marking in body lesser curvature side }\end{array}$ & \\
\hline $\begin{array}{l}\text { Body type A } \\
\text { (B_type A) }\end{array}$ & $\begin{array}{l}\text { Highly accurate mucosal } \\
\text { pattern of } H . \text { pylori infection. } \\
\text { Higher degree of atrophy } \\
(B>A, C) \text { and IM }(A, B) \\
\text { than normal RAC pattern }\end{array}$ & Grade 0: do not exist; Grade 1: exist & Mosaic-like appearance \\
\hline $\begin{array}{l}\text { Body type B } \\
\text { (B_type B) }\end{array}$ & & & Diffuse homogenous redness \\
\hline $\begin{array}{l}\text { Body type C } \\
\text { (B_type C) }\end{array}$ & & & $\begin{array}{l}\text { Untypical-irregular } \\
\text { redness with groove }\end{array}$ \\
\hline $\begin{array}{l}\text { Body spotty } \\
\text { erythema (B_SE) }\end{array}$ & $\begin{array}{l}\text { Suggestive of } H \text {. pylori- } \\
\text { associated gastritis }\end{array}$ & $\begin{array}{l}\text { Grade } 0 \text { : do not exist; Grade } 1 \text { : when it could } \\
\text { be seen only in body greater curvature; Grade } \\
3: \text { when clearly seen in fundus and body; } \\
\text { Grade } 2 \text { : when observed but neither } 1 \text { or } 3\end{array}$ & \\
\hline $\begin{array}{l}\text { Body rugal } \\
\text { hyperplasia } \\
\text { (B_RHG) }\end{array}$ & $\begin{array}{l}\text { Suggestive of } H \text {. pylori- } \\
\text { associated gastritis }\end{array}$ & Grade 0: do not exist; Grade 1: exist & $\begin{array}{l}\text { Gastric fold width was equal } \\
\text { or over } 5 \mathrm{~mm} \text { with the aid } \\
\text { of opening width }(7 \mathrm{~mm}) \text { of } \\
\text { biopsy forcep despite sufficient } \\
\text { air inflation of stomach }\end{array}$ \\
\hline $\begin{array}{l}\text { Body regular } \\
\text { arrangement of } \\
\text { collecting venule } \\
\text { (B_RAC) }\end{array}$ & $\begin{array}{l}\text { Usually } H . \text { pylori free } \\
\text { gastric mucosa. }\end{array}$ & Grade 0: do not exist; Grade 1: exist & \\
\hline $\begin{array}{l}\text { Body exudate } \\
\text { (B_EXU) }\end{array}$ & $\begin{array}{l}\text { Suggestive of } H \text {. pylori- } \\
\text { associated gastritis }\end{array}$ & Grade 0: do not exist; Grade 1: exist & $\begin{array}{l}\text { White mucinous sticky fluid } \\
\text { on the gastric mucosa }\end{array}$ \\
\hline $\begin{array}{l}\text { Body diffuse } \\
\text { erythema (B_DE) }\end{array}$ & $\begin{array}{l}\text { Suggestive of } H \text {. pylori- } \\
\text { associated gastritis }\end{array}$ & $\begin{array}{l}\text { Grade } 0 \text { : do not exist; Grade } 1 \text { : when it could } \\
\text { be identified by close-up observation of mucosa } \\
\text { due to light red color; Grade } 2 \text { : when easily } \\
\text { identified at some distance due to dark red color }\end{array}$ & \\
\hline $\begin{array}{l}\text { Endoscopic } \\
\text { atrophic border } \\
\text { (EAB) }\end{array}$ & Degree of atrophy extent & $\begin{array}{l}\text { Closed type } 1-3(\mathrm{C} 1-3) \text { (cardia saved } \\
\text { from atrophic front); open type } 1-3(\mathrm{O} \\
1-3) \text { (cardia involved with atrophy) }\end{array}$ & $\begin{array}{l}\text { As suggested by Kimura } \\
\text { and Takemoto[13] }\end{array}$ \\
\hline $\begin{array}{l}\text { Antrum visible } \\
\text { vessel break } \\
\left(\text { A_VV_B }_{-}\right)\end{array}$ & $\begin{array}{l}\text { Atrophy of antral mucosa } \\
\text { with features suggestive } \\
\text { of more inflammatory } \\
\text { change in body side }\end{array}$ & Grade 0 : do not exist; Grade 1: exist & $\begin{array}{l}\text { Visible differences in } \\
\text { mucosal thickness and color } \\
\text { between antrum and low } \\
\text { body greater curvature side }\end{array}$ \\
\hline $\begin{array}{l}\text { Antrum visible } \\
\text { vessel }\left(A_{-} \text {VV) }\right.\end{array}$ & Atrophy of antral mucosa & Grade 0: do not exist; Grade 1: exist & \\
\hline $\begin{array}{l}\text { Antrum camouflage } \\
\text { (A_CAM) }\end{array}$ & $\begin{array}{l}\text { Suggestive of } H \text {. pylori- } \\
\text { associated gastritis }\end{array}$ & Grade 0: do not exist; Grade 1: exist & $\begin{array}{l}\text { Mosaic like mucosal change } \\
\text { with peripheral white grooves, } \\
\text { some erythematous mucosal } \\
\text { change could enhance detection }\end{array}$ \\
\hline $\begin{array}{l}\text { Antrum mucosal } \\
\text { edema (A_ME) }\end{array}$ & $\begin{array}{l}\text { Suggestive of } H . \text { pylori- } \\
\text { associated gastritis }\end{array}$ & Grade 0: do not exist; Grade 1: exist & $\begin{array}{l}\text { Soft swelling of mucosa with } \\
\text { mosaic pattern but accompanied } \\
\text { with dark peripheral grooves }\end{array}$ \\
\hline $\begin{array}{l}\text { Antrum intestinal } \\
\text { metaplasia (A_IM) }\end{array}$ & Metaplastic antral mucosa & Grade 0: do not exist; Grade 1: exist & $\begin{array}{l}\text { When whitish plaques were } \\
\text { scattered on the mucosal surface }\end{array}$ \\
\hline $\begin{array}{l}\text { Antrum diffuse } \\
\text { erythema (A_DE) }\end{array}$ & $\begin{array}{l}\text { Suggestive of } H . \text { pylori- } \\
\text { associated gastritis }\end{array}$ & Grade 0 : do not exist; Grade 1: exist & \\
\hline
\end{tabular}


Table 2. Characteristics of Subjects

\begin{tabular}{llll}
\hline & Total & Closed type & Open type \\
\hline Number & 196 & 151 & 45 \\
Age (years \pm SD) & $50.6 \pm 9.0$ & $49.8 \pm 9.0$ & $53.5 \pm 8.8$ \\
Sex (male : female) & $144: 52$ & $112: 39$ & $32: 13$ \\
Hyperacidity(number) & 78 & 72 & 6 \\
\hline Hypoacidity (number) & 73 & 37 & 36 \\
Normoacidity (number) & 45 & 42 & 3 \\
\hline
\end{tabular}

tive feature means risk reducing factor for corresponding acid status. Consequently, various acid statuses would be possible if risk factors and protective factors are coexisted.

\section{Results}

\section{Characteristics of the subjects}

In 196 subjects, there were 144 males and 52 females; the mean age of the subjects was $50.6 \pm 9.0$ years (the mean \pm standard deviation (SD)). Totally 151 subjects were in the closed type and 45 were in the open type. In 151 subjects with closed type, 72 were in the hyperacid state, 37 were in the hypoacid state, and 42 were in the normoacid state. In open type subjects, six were in the hyperacid state, 36 were in the hypoacid state, and three were in the normoacid state. Hypoacidity was observed to be the dominant form of disturbed acid status in the subjects with open type; and hyperacidity or normoacidity were observed as the dominant form in the closed type (Table 2).

\section{Characteristics of the subjects and serological markers subsequent to classification into subgroups}

The mean age of the subjects in the hypoacid group was higher than the subjects in the hyperacid group, but showed no difference between hypoacid and normoacid group. PG I and sex showed no differences between the groups, but PG II and gastrin showed high level in the order of hypoacid, normoacid and hyperacid group (Table 3).

Scores of endoscopic parameters (in multiple comparison test, $=$ means no difference, $>$ means higher score than comparing group)

Endoscopic features that showed higher score in hypoacid group were body xanthoma (= normoacid, > hyperacid), body visible vessel ( $>$ normoacid, $>$ hyperacid), body type B ( $>$ normoacid, $>$ hyperacid), body rugal hyperplasia ( $>$ normoacid, $>$ hyperacid), body exudate ( $>$ normoacid, $>$ hyperacid), body diffuse erythema (= normoacid, $>$ hyperacid), EAB $(>$ normoacid, > hyperacid), and antrum visible vessel (= normoacid, $>$ hyperacid). And mucosal appearances that showed higher score in hyperacid group were body type A (= normoacid, > hypoacid), antrum camouflage (CAM) (= normoacid, > hypoacid) and body RAC (= normoacid, $>$ hypoacid). The score of body type $\mathrm{C}$ was higher in normoacid group, but no difference was shown between hypoacid and hyperacid groups (Table 4).

Univariate and multivariate analyses for disturbed acid status

\section{Univariate analyses for hyperacid}

Overall body RAC (OR: 4.444, $\mathrm{P}=0.003)$, body type A (3.921, $\mathrm{P}<0.001)$, male sex $(2.171, \mathrm{P}=0.029)$, and antrum CAM (2.080, $\mathrm{P}=0.015)$ were the significant risk factors for hyperacid. However, age, body visible vessel, body type B, body rugal hyperplasia, body exudate, body diffuse erythema, antrum visible vessel, and $\mathrm{EAB}$ were the protective features against hyperacid.

In closed type, body RAC (OR: 4.131, $\mathrm{P}=0.018)$, body type A (3.297, $\mathrm{P}=0.001)$, and antrum CAM $(2.303, \mathrm{P}=0.015)$ were the risk factors for hyperacid; age, body type B, body rugal hyperplasia, body exudate, body diffuse erythema, and antrum visible vessel were protective against hyperacid.

In open type, body RAC (OR: 9.250, P =0.049) was the only risk factor for hyperacid. Body type $\mathrm{B}$ and body exudate were the protective factors (Table 5).

Table 3. Demographic and Serological Data of Hypoacid, Normoacid and Hyperacid

\begin{tabular}{llllll}
\hline & Total & Hypoacid & Normoacid & Hyperacid & P-value (hypoacid vs. normoacid vs. hyperacid) \\
\hline Number & 196 & 73 & 45 & 78 & \\
Age (years \pm SD) & $50.6 \pm 9.0$ & $53.4 \pm 8.5$ & $49.9 \pm 9.3$ & $48.4 \pm 8.7$ & 0.002 \\
Sex (male : female) & $144: 52$ & $50: 23$ & $30: 15$ & $64: 14$ & 0.085 \\
Pep_I & $65.1 \pm 25.6$ & $60.9 \pm 24.6$ & $64.1 \pm 23.1$ & $69.5 \pm 27.5$ & 0.116 \\
Pep_II & $22.2 \pm 10.8$ & $28.6 \pm 11.6$ & $21.4 \pm 8.0$ & $16.6 \pm 7.9$ & 0.001 \\
Gastrin & $73.0 \pm 37.7$ & $94.3 \pm 49.9$ & $64.1 \pm 22.8$ & $58.3 \pm 16.5$ & 0.001 \\
I/II ratio & $3.2 \pm 1.2$ & $2.1 \pm 0.4$ & $3.0 \pm 0.2$ & $4.4 \pm 0.9$ & 0.001 \\
\hline
\end{tabular}

Pep_I: pepsinogen I; Pep_II: pepsinogen II. 
Table 4. Scores of Endoscopic Appearances of Hypoacid, Normoacid and Hyperacid

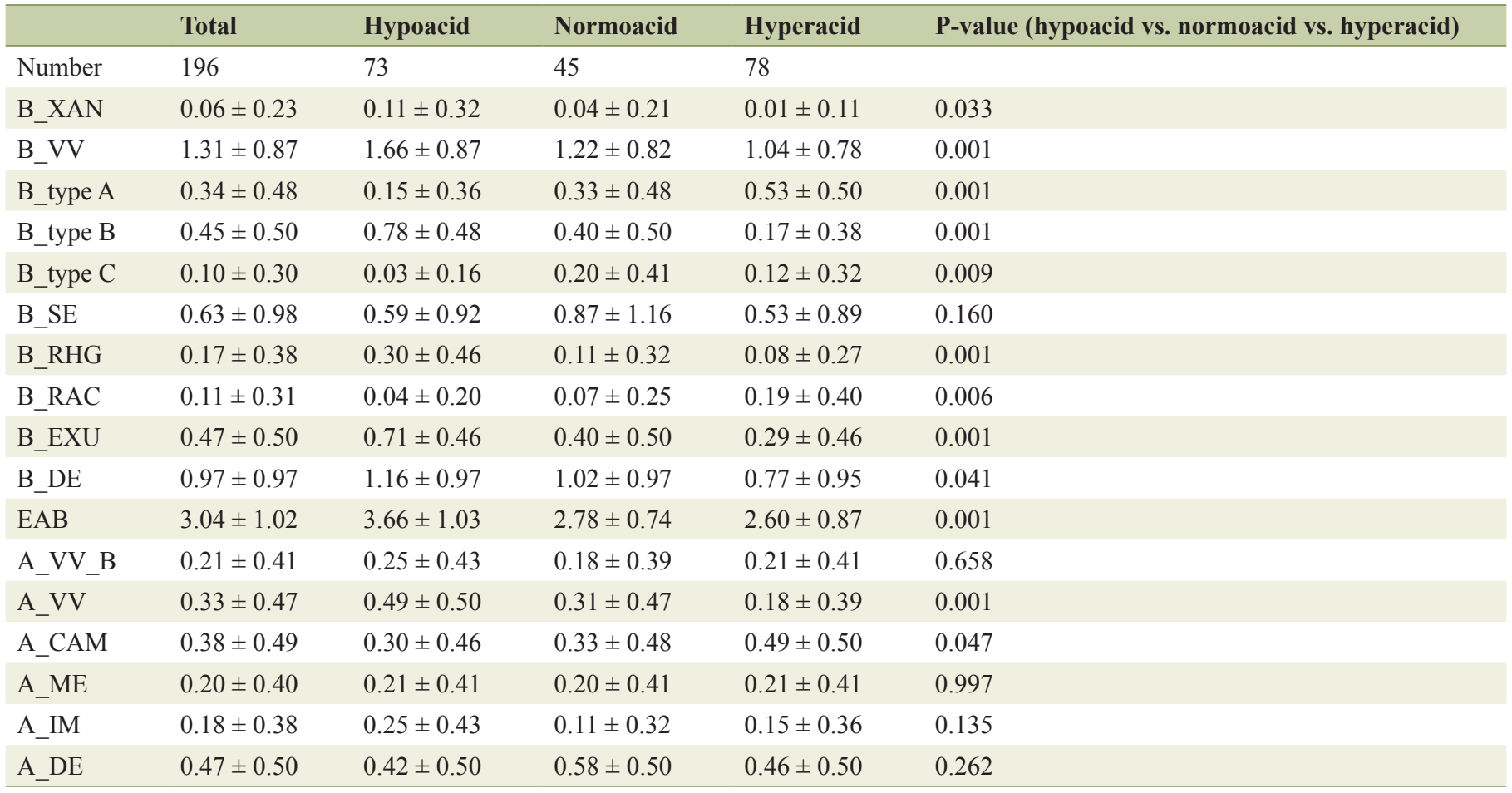

B_XAN: body xanthoma; B_VV: body visible vessel; B_type A: body type A; B_type B: body type B; B_type C: body type C; B_SE: body spotty erythema; B_RHG: body rugal hyperplasia; B_RAC: body regular arrangement of collecting venule; B_EXU: body exudate; B_DE: body diffuse erythema; EAB: endoscopic atrophic border; A_V V_B: antrum visible vessel break; A_VV: antrum visible vessel; A_CAM: antrum camouflage; A_ME: antrum mucosal edema; A_IM: antrum intestinal metaplasia; A_DE: antrum diffuse erythema.

\section{Multivariate analyses for hyperacid}

Overall male sex (OR: 2.389, $\mathrm{P}=0.032)$ was the only significant risk factor for hyperacid.

In closed type, antrum CAM (OR: 2.527, $\mathrm{P}=0.018$ ) was the only risk factor for hyperacid. Age, body type B, and body diffuse erythema were the protective factors against hyperacid.

In open type, no significant risk factors for hyperacid were found, and body exudate was the only significant protective factor against hyperacid (Table 6).

\section{Univariate analyses for hypoacidity}

Overall body type B (OR: 10.573, $\mathrm{P}<0.001$ ), body exudate (4.952, $\mathrm{P}<0.001)$, body xanthoma $(4.923, \mathrm{P}=0.022)$, body rugal hyperplasia $(4.392, \mathrm{P}<0.001), \mathrm{EAB}(3.346, \mathrm{P}<0.001)$, antrum visible vessel $(3.301, \mathrm{P}<0.001)$, body visible vessel (2.215, $\mathrm{P}<0.001)$, body diffuse erythema $(1.382, \mathrm{P}=0.036)$, and age $(1.061, \mathrm{P}=0.001)$ were the risk factors for hypoacidity. However, body type A, body type C, and body RAC were the protective factors against hypoacidity.

In closed type, body type B (OR: 10.025, $\mathrm{P}<0.001)$, body xanthoma (6.788, $\mathrm{P}=0.031)$, body rugal hyperplasia (4.495, $\mathrm{P}=0.001)$, body exudate $(3.052, \mathrm{P}=0.004)$, antrum visible vessel (2.408, $\mathrm{P}=0.033)$, body diffuse erythema (2.026, $\mathrm{P}=$ $0.001)$, and age $(1.088, \mathrm{P}=0.001)$ were the significant factors for hypoacidity. Body type A and antrum CAM were the protective factors for hypoacidity.

In open type, body exudate (OR: $6.250, \mathrm{P}=0.023$ ), body type $\mathrm{B}(5.179, \mathrm{P}=0.038)$, and body visible vessel $(3.593, \mathrm{P}=0.039)$ were the significant risk factors for hypoacidity. There were no significant protective factors against hypoacidity (Table 7).

\section{Multivariate analyses for hypoacidity}

Overall body type B (OR: 6.391, $\mathrm{P}<0.001)$, body rugal hyperplasia $(3.417, \mathrm{P}=0.013)$, EAB $(2.756, \mathrm{P}<0.001)$, and age $(1.066, \mathrm{P}=0.008)$ were significant factors for hypoacidity. None of the factors exhibited any significant protective aspect.

In closed type, body xanthoma (OR: 127.603, $\mathrm{P}=0.002)$, body type B $(12.517, \mathrm{P}<0.001)$, body rugal hyperplasia (5.205, $\mathrm{P}=0.019)$, body diffuse erythema (2.667, $\mathrm{P}=0.002)$, and age $(1.134, \mathrm{P}=0.001)$ were risky parameters for hypoacidity. Antrum diffuse erythema showed protective aspect.

In open type, body exudate (OR: $10.671, \mathrm{P}=0.026$ ) was the only risk factor for hypoacidity. None of the factors exhibited any significant protective aspect (Table 8).

\section{Meaning of camouflage appearance}

As shown in Table 9, comparison of CAM group with non- 
Table 5. Risk Factors for Hyperacid in Univariable Analysis

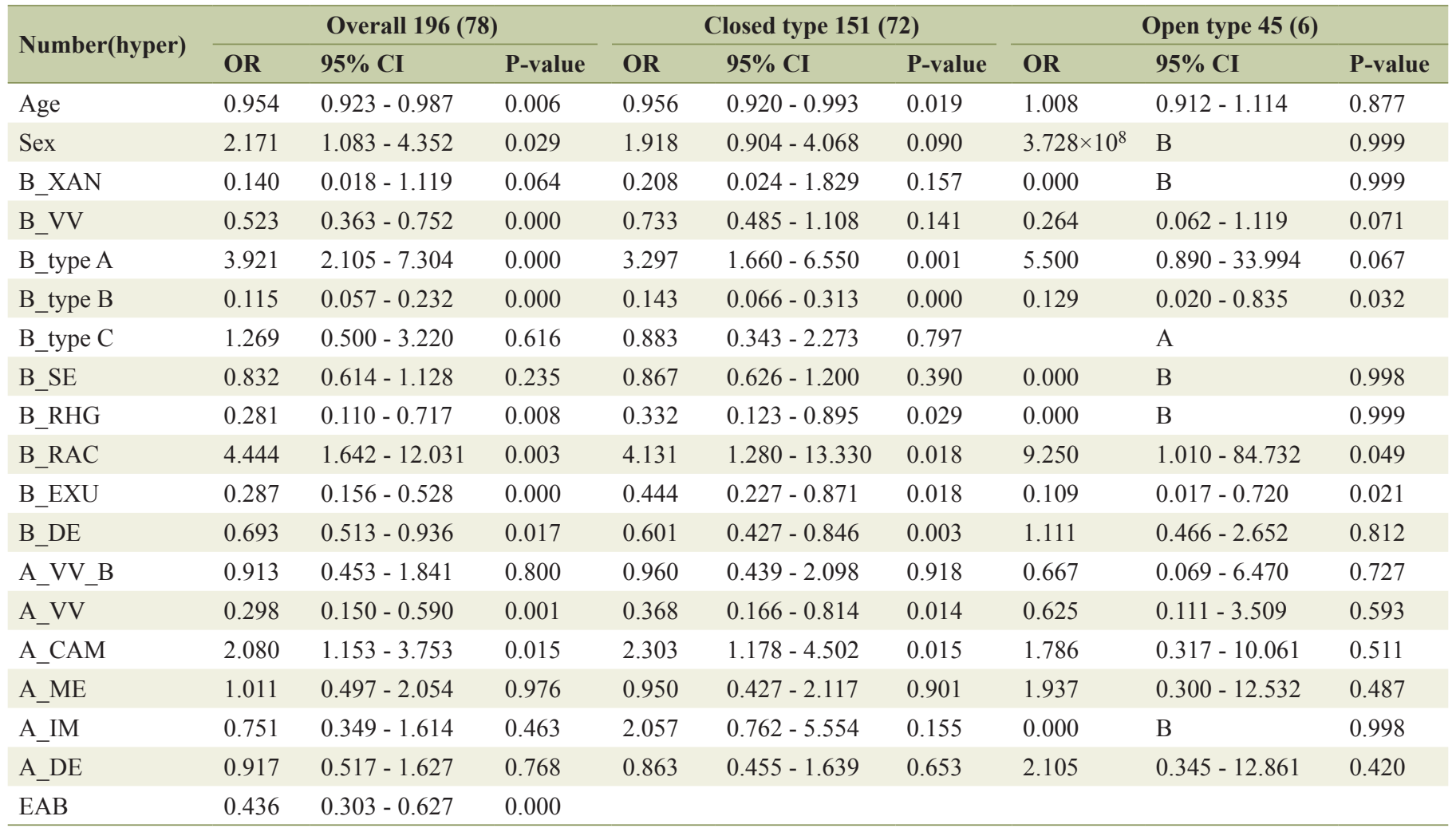

A: There were not any cases; B: indefinite; B XAN: body xanthoma; B VV: body visible vessel; B type A: body type A; B type B: body type B; B type C: body type C; B_SE: body spotty erythema; B_RHG: body rugal hyperplasia; B_RAC: body regular arrangement of collecting venule; B_EXU: body exudate; $B$ _DE: body diffuse erythema; $E A B$ : endoscopic atrophic border; $A \_\bar{V}$ _B: antrum visible vessel break; $A \_V V$ : antrum visible vessel; A_CAM: antrum camouflage; A_ME: antrum mucosal edema; A_IM: antrum intestinal metaplasia; A_DE: antrum diffuse erythema. CI: confidence interval; OR: odds ratio.

CMA group revealed the significantly lower level of PG II in CAM group, no significant other serological or demographic differences were observed.

\section{Discussion}

It was reported that the distribution of $H$. pyori was even in the entire gastric mucosa $[14,15]$. However, intrinsic gastric acidity has been known to determine the outcome of the subject with $H$. pylori infection by either promoting corpus gastritis or not. For example, high acid secretion maintains $H$. pyloriassociated gastritis in the antrum [2], and low acid state could be involved in corpus dominant gastritis. Also the severity of $H$. pylori-associated gastric inflammation could inversely influence gastric acid secretory disturbance resulting in various adverse outcomes such as peptic ulcer diseases, reflux esophagitis, or even gastric cancers.

Based on endoscopic findings, we attempted to find the clues about gastric acid status with the aid of serological information. As one of the most discernible endoscopic findings is $\mathrm{EAB}$, we first divided subjects into two groups as the closed type and open type and revealed each dominant type was hypoacidity in open type and hyperacidity or normoacidity in closed type. This similar observation was originally described in the study by Kimura and Takemoto [13].

The hypoacid group had higher PG II and gastrin level than normoacid or hyperacid group, this was comparable to the findings that PG II could be a surrogate marker of corpus inflammation [16], and corpus gastritis was correlated with disturbance in gastric acid secretion [17, 18]. Referring to these results we would cautiously conclude that in our subjects hypoacidity was mainly dependent on severity of gastritis.

Statistical analyses revealed that in the case of hypoacidity, antrum visible vessel, and most of the $H$. pylori-associated endoscopic parameters representing mucosal inflammation and more atrophy of corpus like body type B [12] were correlated with hypoacidity in overall and closed type. These results were similar in both univariate and multivariate analysis. However, in open type, body exudate, body type B, and body visible vessel contributed to hypoacidity in univariate analysis and only body exudate was meaningful in multivariate analysis. These findings probably mean that in closed type, the severity of gastritis and more atrophic body type might have an influence on the decrease in gastric acid secretion. On the other hand, in open type, the severity of atrophy and persistent inflammation caused by the relatively high amount of $H$. pylori in the exudate [19] with advanced background atrophy might 
Table 6. Risk Factors for Hyperacid in Multivariable Analysis

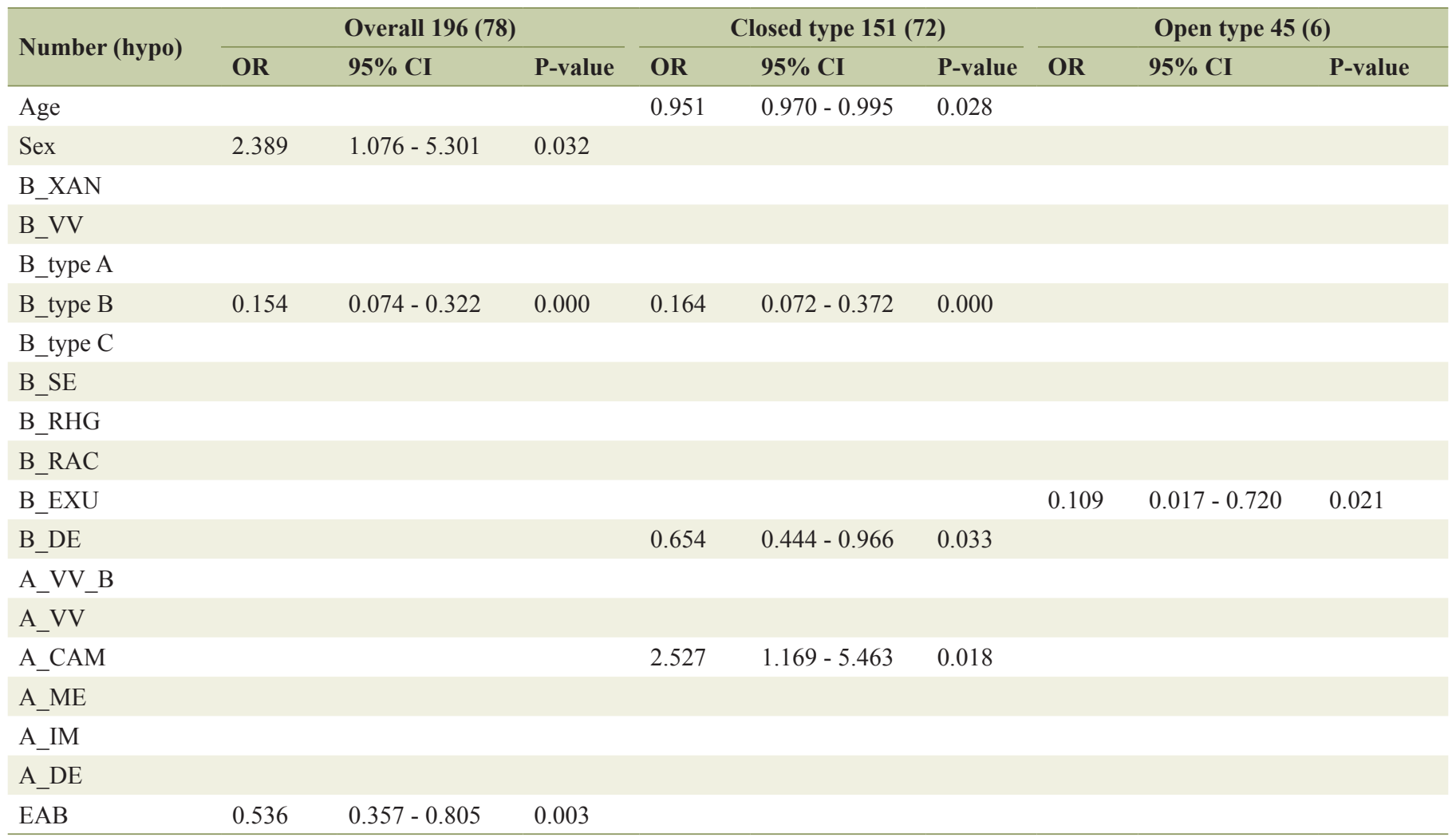

B_XAN: body xanthoma; B_VV: body visible vessel; B_type A: body type A; B_type B: body type B; B_type C: body type C; B_SE: body spotty erythema; B_RHG: body rugal hyperplasia; B_RAC: body regular arrangement of collecting venule; $B$ EXXU: body exudate; $B \_D E$ : body diffuse erythema; EAB: endoscopic atrophic border; A_VV_B: antrum visible vessel break; A_VV: antrum visible vessel; A_CAM: antrum camouflage; A_ME: antrum mucosal edema; A_IM: antrum intestinal metaplasia; A_DE: antrum diffuse erythema; Cl: confidence interval; OR: odds ratio.

determine gastric acid secretion.

For hyperacidity, mucosal appearances showing less atrophy or relatively intact state (body type A, body RAC) were involved in hyperacid state in univariate analysis. Newly added antrum CAM was involved in hyperacidity in univariate and multivariate analysis.

Body findings, such as body xanthoma and RHG probably denoted hypoacidity derived from active inflammation, similar to the report previously published $[20,21]$. Body diffuse erythema means interstitial inflammatory cell infiltration in the atrophy background $[11,22]$. Body type $\mathrm{B}$ represents more histological atrophy than body type A or C [12], of course, body RAC means intact body mucosal state secreting gastric acid normally.

As antrum aspects, antrum diffuse erythema was associated with protective effect in multivariate analysis for closed type hypoacidity, this might be due to the fact that antrum diffuse erythema was one of the representative features of mononuclear cell infiltration related to antral gastric $(\mathrm{G})$ cell hyperfunction resulting in increase in gastric acid by hypergastrinemia [11, 23]. Antrum CAM was involved in overall and closed type hyperacidity, however only PG II level was lower in antrum CAM group than in non-antrum CAM group and no other serological differences were observed, which mean that considering PG II as a corpus inflammatory sur- rogate marker, contribution of antrum CAM for hyperacidity might be a secondary change caused by increased body acid (Table 9). As antrum CAM basically consists of some component of erythema, we could not exclude the possibility of antrum hyperfunction in antrum CAM, hence further study is required. In only univariate analysis, antrum visible vessel was related to overall hypoacidity, and antrum IM in open type hypoacidity. As antral atrophy progresses, corpus migration of $H$. pylori could be accelerated and this may cause aggravation of corpus gastritis resulting in decrease in gastric acid [24-26]. This antral induced hypoacidity might partly support the retrospective-case control study suggesting that atrophic gastritis of the antrum and body of the stomach are independent risk factors for GC [27]. And a study by Shiotani et al [28] that showed higher frequency of IM and inflammation at the antrum was associated with GC could also be supported by our result.

Male gender was correlated with hyperacidity and aging was related to hypoacidity similar to the results of previous study [29].

It could be hypothesized that in western countries or in subjects with plenty of gastric acid, hypoacidity could possibly be induced by advanced antrum pathology plus disturbed acid secretion by acquired factors like cigarette or salt, low intake of fresh vegetables, which might allow $H$. pyori to mi- 
Table 7. Risk Factors for Hypoacid in Univariable Analysis

\begin{tabular}{|c|c|c|c|c|c|c|c|c|c|}
\hline \multirow{2}{*}{ Number (hypo) } & \multicolumn{3}{|c|}{ Overall 196 (73) } & \multicolumn{3}{|c|}{ Closed type 151 (37) } & \multicolumn{3}{|c|}{ Open type 45 (36) } \\
\hline & OR & $95 \%$ CI & P-value & OR & $95 \%$ CI & P-value & OR & $95 \%$ CI & P-value \\
\hline Age & 1.061 & $1.024-1.099$ & 0.001 & 1.088 & $1.036-1.144$ & 0.001 & 0.937 & $0.854-1.028$ & 0.170 \\
\hline B_XAN & 4.923 & $1.263-19.197$ & 0.022 & 6.788 & $1.190-38.720$ & 0.031 & 1.000 & $0.098-10.219$ & 0.000 \\
\hline B_VV & 2.215 & $1.521-3.225$ & 0.000 & 1.211 & $0.757-1.937$ & 0.425 & 3.293 & $1.070-12.072$ & 0.039 \\
\hline B_type C & 0.164 & $0.037-0.730$ & 0.018 & 0.305 & $0.067-1.381$ & 0.123 & & A & \\
\hline B_SE & 0.937 & $0.693-1.265$ & 0.670 & 0.866 & $0.584-1.284$ & 0.474 & 1.566 & $0.578-4.244$ & 0.377 \\
\hline B_RHG & 4.392 & $1.982-9.735$ & 0.000 & 4.495 & $1.778-11.363$ & 0.001 & $5.592 \times 10^{8}$ & $\mathrm{~B}$ & 0.999 \\
\hline B_RAC & 0.250 & $0.071-0.881$ & 0.031 & 0.170 & $0.022-1.330$ & 0.091 & 0.206 & $0.025-1.719$ & 0.144 \\
\hline A_VV & 3.301 & $1.770-6.155$ & 0.000 & 2.408 & $1.075-5.395$ & 0.033 & 1.257 & $0.287-5.499$ & 0.761 \\
\hline A_CAM & 0.570 & $0.308-1.053$ & 0.073 & 0.426 & $0.185-0.985$ & 0.046 & 0.707 & $0.161-3.105$ & 0.646 \\
\hline A_ME & 1.014 & $0.495-2.078$ & 0.970 & 1.154 & $0.464-2.867$ & 0.758 & 0.483 & $0.096-2.423$ & 0.376 \\
\hline A_IM & 2.041 & $0.975-4.271$ & 0.058 & 0.326 & $0.072-1.484$ & 0.147 & $7.27 \times 10^{8}$ & $\mathrm{~B}$ & 0.998 \\
\hline A_DE & 0.726 & $0.405-1.301$ & 0.282 & 0.542 & $0.251-1.168$ & 0.118 & 0.800 & $0.184-3.473$ & 0.766 \\
\hline EAB & 3.346 & $2.204-5.082$ & 0.000 & & & & & & \\
\hline
\end{tabular}

A: there were not any cases; B: indefinite; B_XAN: body xanthoma; B_VV: body visible vessel; B_type A: body type A; B_type B: body type B; B_type C: body type C; B_SE: body spotty erythema; B_RHG: body rugal hyperplasia; B_RAC: body regular arrangement of collecting venule; $B$ EXU: body exudate; B_DE: body diffuse erythema; EAB: endoscopic atrophic border; A_VV_B: antrum visible vessel break; A_VV: antrum visible vessel; A CAM: antrum camouflage; A ME: antrum mucosal edema; A IM: antrum intestinal metaplasia; A DE: antrum diffuse erythema; CI: confidence interval; OR: odds ratio.

grate into corpus more easily. Also this western type might be atrophy dependent rather than gastritis in reducing gastric acid [30]. In contrast, in oriental area like Japan, hypoacidity could mainly occur due to rapid corpus migration of $H$. pylori by a genetically determined shortage of acid reservoir and additional harmful environmental factors, which might be dependent on the severity of gastritis in determining gastric acidity, although additional atrophy could further aggravate gastric acid shortage. Consequently many possible combinations of western and oriental type could exist and population with oriental type might benefit from $H$. pylori eradication for the recovery of acid secretion except for the severe corpus atrophy [4, 24].

Considering all these facts, awareness about hypoacidity would be a great tool in proper management of patient. During endoscopy session, if closed type EAB encountered, most cases would be normoacid or hyperacid state. However, when any one of hypoacid features like body xanthoma, body type $\mathrm{B}$, body rugal hyperplasia or body diffuse erythema was accompanied, we should consider early $H$. pylori eradication to prevent ongoing hypoacid state. Of course in open type EAB, we should take into account $H$. pylori eradication and environmental factor correction like smoking cessation or low salt diet etc.
Antrum CAM could be a useful parameter for recovery of acid secretion after eradication if it is secondary change of hyperacid as our study. When antrum CAM was accompanied with closed type EAB, one might consider hyperacid related disease like duodenal ulcer or reflux esophagitis.

Hematin was a predictive endoscopic finding for hyperacidity, swelling of areae gastricae and open type gastric atrophy were the endoscopic findings for hypoacidity in a Japanese study [31]. However, we used other various endoscopic findings and disclosed explainable mechanism for endoscopic parameters in disturbed acid status.

This study had several limitations. Histologic confirmation to support endoscopic finding was omitted, however this study was focused on evaluating functional aspect of stomach by endoscopy and most of endoscopic parameters were histologically verified in previous studies. Of course newly added antrum CAM was used only in our center, we are seriously considering multicenter study to correct this drawback in near future. Also we did not depend on direct measurement of gastric acid. However, reference value of pepsinogen test was the same (positive finding of PG test were PG I/II ratio $\leq 3.0$ and PGI $\leq 70 \mathrm{ng} / \mathrm{mL}$ ) as Japan, which means that our serological results were not different from the Japanese study [9]. Additionally, there existed an inevitable bias to implement 
Table 8. Risk Factors for Hypoacid in Multivariable Analysis

\begin{tabular}{|c|c|c|c|c|c|c|c|c|c|}
\hline \multirow{2}{*}{ Number (hypo) } & \multicolumn{3}{|c|}{ Overall 196 (73) } & \multicolumn{3}{|c|}{ Closed type 151 (37) } & \multicolumn{3}{|c|}{ Open type 45 (36) } \\
\hline & OR & $95 \%$ CI & P-value & OR & $95 \%$ CI & P-value & OR & $95 \%$ CI & P-value \\
\hline Age & 1.066 & $10.170-1.118$ & 0.008 & 1.134 & $1.056-1.217$ & 0.001 & & & \\
\hline B_XAN & & & & 127.603 & $5.867-2775.034$ & 0.002 & & & \\
\hline \multicolumn{10}{|l|}{ B_VV } \\
\hline \multicolumn{10}{|l|}{ B_type C } \\
\hline \multicolumn{10}{|l|}{ B_SE } \\
\hline B_RHG & 3.417 & $1.289-9.056$ & 0.013 & 5.205 & $1.319-20.543$ & 0.019 & & & \\
\hline \multicolumn{10}{|l|}{ B_RAC } \\
\hline \multicolumn{10}{|l|}{ A_VV_B } \\
\hline \multicolumn{10}{|l|}{ A_VV } \\
\hline \multicolumn{10}{|l|}{ A_CAM } \\
\hline \multicolumn{10}{|l|}{ A_ME } \\
\hline \multicolumn{10}{|l|}{ A_IM } \\
\hline A_DE & & & & 0.161 & $0.047-0.554$ & 0.004 & & & \\
\hline EAB & 2.756 & $1.717-4.424$ & 0.000 & & & & & & \\
\hline
\end{tabular}

B_XAN: body xanthoma; B_VV: body visible vessel; B_type A: body type A; B_type B: body type B; B_type C: body type C; B_SE: body spotty erythema; B_RHG: body rugal hyperplasia; B_RAC: body regular arrangement of collecting venule; $B$ EXU: body exudate; $B$ _DE: body diffuse erythema; EAB: endoscopic atrophic border; A_VV_B: antrum visible vessel break; A_VV: antrum visible vessel; A_CAM: antrum camouflage; A_ME: antrum mucosal edema; A_IM: antrum intestinal metaplasia; A_DE: antrum diffuse erythema; CI: confidence interval; OR: odds ratio.

Japanese results directly on our subjects, because of different sexual and age distributions even if there was a similar ethnic background. Actually most of our subjects were employees of regional companies, being younger and male dominant. Nevertheless, we showed that several aspects of our results, such as $\mathrm{EAB}$, male gender, age, etc. were similar to the previous studies using direct measurement of gastric acid, this might be an evidence that PG level in our study could be an alternative to direct measurement of gastric acid.

Needless to state that when a physician wishes to evaluate specific diseases it should be practical to employ each coun- try's specific and easily available methods, such as a pepsinogen test in Japan and endoscopy in Korea for screening GC. This was our main aim to conduct this study. We could have obtained more detailed and exact results if there had been Korea-specific data based on direct measurement of gastric acidity. In near future, nation-wide study is needed.

\section{Conflict of Interest}

There is no conflict of interest.

Table 9. Serological and Demographic Meaning of Antrum Camouflage

\begin{tabular}{lllll}
\hline & Total & CAM & Non-CAM & P-value (CAM vs. non-CAM) \\
\hline Number & 151 & 75 & 121 & 0.873 \\
Age (years \pm SD) & $49.8 \pm 9.0$ & $50.5 \pm 7.9$ & $50.7 \pm 9.7$ & 0.536 \\
Sex (male : female) & $112: 39$ & $54: 21$ & $90: 31$ & 0.103 \\
Pep_I & $68.4 \pm 24.6$ & $61.3 \pm 22.4$ & $67.4 \pm 27.3$ & 0.015 \\
Pep_II & $21.7 \pm 10.4$ & $19.8 \pm 9.5$ & $23.7 \pm 11.3$ & 0.382 \\
Gastrin & $68.2 \pm 32.4$ & $70.0 \pm 35.8$ & $74.9 \pm 38.8$ & 0.067 \\
\hline I/II ratio & $3.5 \pm 1.1$ & $3.4 \pm 1.2$ & $3.1 \pm 1.2$ & \\
\hline
\end{tabular}

Pep_I: pepsinogen I; Pep_II: pepsinogen II. 


\section{References}

1. Zhu H, Pace F, Sangaletti O, Bianchi Porro G. Gastric acid secretion and pattern of gastroesophageal reflux in patients with esophagitis and concomitant duodenal ulcer. A multivariate analysis of pathogenetic factors. Scand J Gastroenterol. 1993;28(5):387-392.

2. Graham DY. Helicobacter pylori: its epidemiology and its role in duodenal ulcer disease. J Gastroenterol Hepatol. 1991;6(2):105-113.

3. Konturek SJ, Starzynska T, Konturek PC, Karczewska E, Marlicz K, Lawniczak M, Jaroszewicz-Heigelman H, et al. Helicobacter pylori and CagA status, serum gastrin, interleukin-8 and gastric acid secretion in gastric cancer. Scand J Gastroenterol. 2002;37(8):891-898.

4. El-Omar EM, Oien K, El-Nujumi A, Gillen D, Wirz A, Dahill S, Williams C, et al. Helicobacter pylori infection and chronic gastric acid hyposecretion. Gastroenterology. 1997;113(1):15-24.

5. Lee A, Dixon MF, Danon SJ, Kuipers E, Megraud F, Larsson H, Mellgard B. Local acid production and Helicobacter pylori: a unifying hypothesis of gastroduodenal disease. Eur J Gastroenterol Hepatol. 1995;7(5):461-465.

6. Sipponen P, Hyvarinen H, Siurala M. H. pylori corpus gastritis - relation to acid output. J Physiol Pharmacol. 1996;47(1):151-159.

7. Uemura N, Okamoto S, Yamamoto S, Matsumura N, Yamaguchi S, Yamakido M, Taniyama K, et al. Helicobacter pylori infection and the development of gastric cancer. N Engl J Med. 2001;345(11):784-789.

8. Correa P. Human gastric carcinogenesis: a multistep and multifactorial process - First American Cancer Society Award Lecture on Cancer Epidemiology and Prevention. Cancer Res. 1992;52(24):6735-6740.

9. Iijima K, Koike T, Abe Y, Shimosegawa T. Cutoff serum pepsinogen values for predicting gastric acid secretion status. Tohoku J Exp Med. 2014;232(4):293-300.

10. Nomura S, Terao S, Adachi K, Kato T, Ida K, Watanabe H, Shimbo T, et al. Endoscopic diagnosis of gastric mucosal activity and inflammation. Dig Endosc. 2013;25(2):136146.

11. Nomura S, Ida K, Terao S, Adachi K, Kato T, Watanabe $\mathrm{H}$, Shimbo T, et al. Endoscopic diagnosis of gastric mucosal atrophy: multicenter prospective study. Dig Endosc. 2014;26(6):709-719.

12. Cho JH, Chang YW, Jang JY, Shim JJ, Lee CK, Dong $\mathrm{SH}$, Kim HJ, et al. Close observation of gastric mucosal pattern by standard endoscopy can predict Helicobacter pylori infection status. J Gastroenterol Hepatol. 2013;28(2):279-284.

13. Kimura K, Takemoto T. An endoscopic recognition of the atrophic border and its significance in chronic gastritis endoscopy. Endoscopy. 1969;1(3):87-97.

14. Genta RM, Graham DY. Comparison of biopsy sites for the histopathologic diagnosis of Helicobacter pylori: a topographic study of $\mathrm{H}$. pylori density and distribution. Gastrointest Endosc. 1994;40(3):342-345.

15. Bayerdorffer E, Lehn N, Hatz R, Mannes GA, Oertel H,
Sauerbruch T, Stolte M. Difference in expression of Helicobacter pylori gastritis in antrum and body. Gastroenterology. 1992;102(5):1575-1582.

16. Massarrat S, Haj-Sheykholeslami A, Mohamadkhani A, Zendehdel N, Aliasgari A, Rakhshani N, Stolte M, et al. Pepsinogen II can be a potential surrogate marker of morphological changes in corpus before and after $\mathrm{H}$. pylori eradication. Biomed Res Int. 2014;2014:481607.

17. Chuang CH, Sheu BS, Yang HB, Kao AW, Cheng HC, Yao WJ. Hypergastrinemia after Helicobacter pylori infection is associated with bacterial load and related inflammation of the oxyntic corpus mucosa. J Gastroenterol Hepatol. 2004;19(9):988-993.

18. Lee OJ, Lee EJ, Kim HJ. Correlations among gastric juice $\mathrm{pH}$ and ammonia, Helicobacter pylori infection and gastric mucosal histology. Korean J Intern Med. 2004;19(4):205-212.

19. Ohkusa T, Okayasu I, Yamada M, Hosoi H, Yamanaka A, Fujiki K, Tamura Y, et al. A high frequency of detection of Helicobacter pylori in whitish exudate of gastric ulcer. J Clin Gastroenterol. 1991;13(6):649-655.

20. Watanabe M, Kato J, Inoue I, Yoshimura N, Yoshida T, Mukoubayashi C, Deguchi H, et al. Development of gastric cancer in nonatrophic stomach with highly active inflammation identified by serum levels of pepsinogen and Helicobacter pylori antibody together with endoscopic rugal hyperplastic gastritis. Int J Cancer. 2012;131(11):2632-2642.

21. Kitamura S, Muguruma N, Okamoto K, Tanahashi T, Fukuya A, Tanaka K, Fujimoto D, et al. Clinicopathological assessment of gastric xanthoma as potential predictive marker of gastric cancer. Digestion. 2017;96(4):199-206.

22. Kodama M, Murakami K, Okimoto T, Sato R, Uchida M, Abe T, Shiota S, et al. Ten-year prospective followup of histological changes at five points on the gastric mucosa as recommended by the updated Sydney system after Helicobacter pylori eradication. J Gastroenterol. 2012;47(4):394-403.

23. Liu Y, Vosmaer GD, Tytgat GN, Xiao SD, Ten Kate FJ. Gastrin (G) cells and somatostatin (D) cells in patients with dyspeptic symptoms: Helicobacter pylori associated and non-associated gastritis. J Clin Pathol. 2005;58(9):927-931.

24. Ruiz B, Correa P, Fontham ET, Ramakrishnan T. Antral atrophy, Helicobacter pylori colonization, and gastric $\mathrm{pH}$. Am J Clin Pathol. 1996;105(1):96-101.

25. Kekki M, Maaroos HI, Sipponen P, Uibo R, Tammur R, Tamm A, Villako K. Grade of Helicobacter pylori colonisation in relation to gastritis: a six-year populationbased follow-up study. Scand J Gastroenterol Suppl. 1991;186:142-150.

26. Niemela S, Karttunen T, Kerola T. Helicobacter pyloriassociated gastritis. Evolution of histologic changes over 10 years. Scand J Gastroenterol. 1995;30(6):542-549.

27. Kodama M, Murakami K, Okimoto T, Abe H, Sato R, Ogawa R, Mizukami K, et al. Histological characteristics of gastric mucosa prior to Helicobacter pylori eradication may predict gastric cancer. Scand J Gastroenterol. 2013;48(11):1249-1256. 
28. Shiotani A, Iishi H, Uedo N, Kumamoto M, Nakae Y, Ishiguro S, Tatsuta $\mathrm{M}$, et al. Histologic and serum risk markers for noncardia early gastric cancer. Int J Cancer. 2005;115(3):463-469.

29. Derakhshan MH, El-Omar E, Oien K, Gillen D, Fyfe V, Crabtree JE, McColl KE. Gastric histology, serological markers and age as predictors of gastric acid secretion in patients infected with Helicobacter pylori. J Clin Pathol.
2006;59(12):1293-1299.

30. Katelaris PH, Seow F, Lin BP, Napoli J, Ngu MC, Jones DB. Effect of age, Helicobacter pylori infection, and gastritis with atrophy on serum gastrin and gastric acid secretion in healthy men. Gut. 1993;34(8):1032-1037.

31. Hatta W, Iijima K, Koike T, Kondo Y, Ara N, Asanuma K, Uno K, et al. Endoscopic findings for predicting gastric acid secretion status. Dig Endosc. 2015;27(5):582-589. 